\title{
EFEKTIVITAS MGMP DALAM PENINGKATAN PROFESIONALISME GURU MATA PELAJARAN UMUM DI MTS
}

\author{
Lisa'diyah Ma'rifataini \\ Puslitbang Pendidikan Agama dan Keagamaan | Balitbang dan Diklat Kemenag RI \\ Jl. MH Thamrin No.06 Jakarta Pusat | Email: lisa.litbang@gmail.com,
}

\section{Abstract}

This research is to identify the effectiveness of the course teachers' consultation "Efektifitas Musyawarah Guru Mata Pelajaran" (MGMP) in developing the professionalism of the general course teachers in Madrasah Tsanawiyah (MTs). This research uses mixed method approach with description analysis as its presentation. The chief of MGMP appears as the correspondent which has become a member of MGMP, kasiMapenda, and the head of madrasah also the supervisor of the establishment of MGMP in seven provinces. This research applies the stratified random sampling as its method sampling. The result of this research shows the lack of effectiveness in consulting the general course teachers' professionalism based on the goal and structure of MGMP. This is based on the resulting discovery that identifies only the component of the MGMP towards the teachers' needs appears to be effective compared by the whole six other components involved.

Keyword: effectiveness, consultation of the general course teacher (MGMP), professionalism, teacher, Madrasah Tsanawiyah (MTs)

\begin{abstract}
Abstraks
Penelitian ini bertujuan untuk melihat Efektivitas MGMP dalam Peningkatan Profesionalisme Guru Mata Pelajaran Umum di MTs. Penelitian ini menggunakan pendekatan mixed method dengan metode analisisnya deskriptif presentatif. Sebagai respondennya adalah Ketua MGMP, Guru yang menjadi anggota MGMP, Kasi Mapenda, Ketua Pokjawas, dan Kepala Madrasah sebagai pembina sanggar MGMP yang tersebar di tujuh propinsi. Teknik pengambilan sampel dengan menggunakan Stratified Random Sampling. Hasil penelitian menunjukkan terdapat kecenderungan MGMP di MTs belum efektif dalam membina profesionalitas guru mata pelajaran umum sesuai dengan tujuan dan fungsi MGMP, yang didasarkan atas temuan hasil penelitian bahwa dari 6 komponen instrumen efektivitas MGMP hanya komponen efektivitas MGMP terhadap Kebutuhan Guru saja yang tergolong efektif, 2 komponen cukup efektif dan 3 komponen instrumen yang lainnya hasilnya cenderung kurang efektif.
\end{abstract}

Kata kunci: Efektifitas, MGMP, Profesionalisme, Guru, MTs

\section{PENDAHULUAN}

Padakenyataannya pendidikanmerupakan suatu usaha yang tidak mudah melainkan penuh dengan tantangan. Pendidikan selalu berubah dari waktu ke waktu sesuai dengan perkembangan masyarakat. Pendidikan harus selalu menyesuaikan dengan perkembangan yang terjadi di masyarakat mengingat sumber daya di segala bidang menggantungkan pada keberhasilan pendidikan. Sumber daya yang berkualitas sebagai outcome dari pendidikan sangat diperlukan untuk membangun masyarakat agar dapat bersaing secara internasional. Untuk dapat menghasilkan sumberdaya yang berkualitas

Naskah diterima 30 Februari 2013. Revisi pertama, 27 Maret 2013. Revisi kedua, 1 April 2013 dan revisi terahir 5 April 2013. 
maka kualitas pendidikan menjadi sorotan utama. Berbagai kegiatan diselenggarakan agar guru dapat memperbaiki kinerjanya sehingga dapat dikatakan sebagai guru yang profesional. Kegiatan ilmiah seperti seminar, pendidikan dan pelatihan dilaksanakan untuk meningkatkan profesionalitas guru. Sesama guru mata pelajaran tertentu membentuk forum kegiatan yang dapat digunakan untuk mewadahi kepentingan guru dalam menigkatkan profesionalitasnya.

Undang-undang Nomor 14 Tahun 2005 tentang Guru dan Dosen menyebutkan bahwa guru mempunyai fungsi, peran dan kedudukan yang strategis dalam pembangunan nasional dibidang pendidikan. Oleh karena itu profesional guru diperlukan dalam upaya peningkatan mutu pendidikan. Guru yang profesional adalah guru yang kompeten apabila secara nyata ia mampu menjalankan tugas keguruannya secara berkeahlian sesuai dengan tuntutan jabatan keguruannya yaitu mampu membelajarkan siswa yang dibimbingnya secara efisien, efektif dan terpadu.

Keberadaan dan fungsi guru merupakan salah satu faktor yang sangat signifikan dalam dunia pendidikan, karena guru merupakan bagian terpenting dalam proses belajar mengajar. Oleh sebab itu, setiap upaya peningkatan kualitas pendidikan di tanah air tidak dapat dilepas dari berbagai hal yang berkaitan dengan eksistensi guru itu sendiri. Keberhasilan pendidikan di suatu madrasah tidak terlepas dari peranan guru. Tinggi rendahnya mutu pendidikan di madrasah berkorelasi positif dengan tinggi rendahnya mutu guru. Oleh karena itu, kebijakan pemerintah dan pengelola madrasah yang terkait dengan peningkatan mutu guru harus diutamakan. ${ }^{1}$

Seiring dengan diterbitkannya Peraturan Mentri Pendidikan Nasioanal RI No. 16

${ }^{1}$ Nugraha S. Mulyasa, Meningkatkan Mutu Madrasah Melalui Pemberdayaan MGMP (Internet:http:// h4j4r. multiply.com/jounal/item/6/), di akses Rabu 15 Desember 2011
Tahun 2007 tentang standar akademik dan kualifikasi guru, maka setiap guru dituntut meningkatkan profesionalisme, yaitu setiap guru harus meningkatkan kompetensinya, baik kompetensi pedagogik, kepribadian sosial maupun profesional. Dengan kompetensi ini guru diharapkan dapat merencanakan dan melaksanakan pembelajaran dengan baik, menjadi teladan bagi siswa serta mampu mengembangkan profesinya. ${ }^{2}$

Mengingat pentingnya meningkatkan mutu guru, maka peningkatan profesionalisme guru melalui pemberdayaan MGMP sangat diperlukan. Karena hingga kini, kita tidak bisa menutup mata bahwa mutu guru masih tergolong rendah. ${ }^{3}$ Melalui kegiatan MGMP guru diharapkan bisa meningkatkan kemampuan profesionalitasnya, Lewat forum MGMP guru lebih terampil merencanakan, melaksanakan, dan membuat evaluasi program pembelajaran. Melalui wadah ini mutu guru dapat terwujud, dan pada gilirannya, mutu madrasah semakin tinggi menjadi kenyataan. ${ }^{4}$

Suadilah dan Agustina menyatakan bahwa kegiatan MGMP diharapkan dapat berfungsi dalam meningkatkan mutu pendidik (guru) dan tentunya hal ini akan berimbas pada peningkatan mutu pembelajaran di sekolah ${ }^{5}$. MGMP sebagai wadah profesi yang strategis dalam memberdayakan guru, agar guru benarbenar menjadi guru yang profesional, dan menguasai kompetensi sesuai standar pendidik yang disyaratkan dalam SNP, Pemerintahpun telah memberikan perhatian dengan

${ }^{2}$ Dirjen Pendidikan Islam. Kumpulan Undang-Undang dan Peraturan Pemerintah RI Tentang Pendidikan Bab IV tentang Guru Pasal 10 I (Jakarta: Departemen Agama, 2007) h. 78

${ }^{3}$ Berdasarkan hasil Penelitian Puslitbang Pendidikan Agama dan Keagamaan tahun 2007, yang dilakukan oleh Sumarni, MSi dkk, menyatakan bahwa kompetensi profesional guru mata pelajaran umum di madrasah masih rendah, yaitu rata-rata 53,4.

${ }^{4}$ Nugraha S. Mulyasa, "Loc. Cit"

${ }^{5}$ Suaidillah dan Ella Agustina, Memberdayakan KKG dan MGMP (Internet: http://www. radarbanjarmasin. com/berita/index.asp?Berita=Opini\&id $=60089$, diakses Selasa 10 Januari 2012 
menyalurkan blockgrant untuk MGMP baik dari Depdiknas maupun Departemen Agama.

Sebenarnya peningkatan kemampuan professional guru merupakan hak setiap guru. Tujuan akhir peningkatan kemampuan profesional guru adalah bertumbuh kembangnya profesionalisme. Karena itu, peningkatan kemampuan profesional guru di MTs seharusnya diarahkan pada pembinaan kemampuan profesional dan sekaligus pembinaan komitmennya. Dalam rangka itu, peningkatan kemampuan profesional guru MTs melalui MGMP perlu dilakukan secara kontinu seiring dengan perkembangan ilmu pengetahuan dan teknologi pendidikan.

Keberadaan MGMP khususnya di MTs sudah cukup lama namun selama ini belum banyak yang mengkajinya. Berdasarkan hal tersebut, maka perlu dilakukan penelitian secara mendalam tentang "Efektivitas MGMP dalam Peningkatan Profesionalisme Guru Mata Pelajaran Umum di MTs". Berdasarkan latar belakang diatas, rumusan pertanyaan tulisan ini adalah: 1) Bagaimanakah Efektivitas MGMP Mata Pelajaran Umum dalam Peningkatan Profesionalisme guru di MTs? Dan 2) Problema apa yang dihadapi MGMP Mata Pelajaran Umum di MTs dalam Peningkatan Profesionalisme Guru?

\section{Kerangka Konsep}

\section{Efektivitas}

Kata efektif berasal dari bahasa Inggris yaitu effective yang berarti berhasil atau sesuatu yang dilakukan berhasil dengan baik. Kamus ilmiah populer efektivitas sebagai ketepatan penggunaan, hasil guna atau menunjang tujuan. Efektivitas adalah suatu ukuran yang menyatakan seberapa jauh target telah tercapai, dimana makin besar presentase target yang dicapai, makin tinggi tingkat efektivitasnya". ${ }^{6}$ Dengan demikian pengertian

${ }^{6}$ Hidayat, devinisi/pengertian efektifitas (Internet http://dansite.wordpress.com/2009/03/28, diakses Senin efektivitas secara umum menunjukan sampai seberapa jauh tercapainya suatu tujuan yang terlebih dahulu ditentukan.

Menurut Morrisey, efektivitas adalah strategi yang mendorong terhadap terciptanya sutu keselarasan secara sempurna antara organisasi dengan lingkungannya dan antara organisasi dengan pencapaian tujuannya. Efektivitas adalah melakukan hal-hal yang benar sesuai dengan tujuan. ${ }^{7}$ Efektif adalah membuat keputusan dengan tepat dan mengimplementasikannya dengan sukses. ${ }^{8}$ Efektivitas adalah pemanfaatan sumber daya, sarana dan prasarana yang keberhasilannya dilihat dari segi tercapai tidaknya sasaran yang telah ditetapkan. Jika hasil kegiatan semakin mendekati sasaran, berarti makin tinggi efektivitasnya. ${ }^{9}$

Dari beberapa pengertian efektivitas tersebut diatas dapat disimpulkan bahwa efektivitas adalah suatu ukuran yang menyatakan seberapa jauh target yang telah dicapai oleh manajemen yang dalam hal ini organisasi MGMP, yang mana target tersebut sudah ditentukan terlebih dahulu sesuai dengan tujuan dan fungsi MGMP.

\section{Profesionalisme Guru}

Pekerjaan guru merupakan sebuah profesi, dan guru yang profesional harus memenuhi standar kompetensi guru yaitu kompetensi kognitif di antaranya adalah menguasai materi pembelajaran, menguasai berbagai metode yang akan disesuaikan dengan materi pembelajaran, kompetisi yang afektif yaitu meliputi harga diri, mempunyai kepedulian yang tinggi dalam pengembangan pendidikan

\footnotetext{
9 Januari 2012

7 George L. Morrisey. Pedoman Perencanaan Taktis. Jakarta: Prenhallindo. 2002, h, 23

8 Ricky W.Griffin. Manajemen. Jakarta: Erlangga, 2004 , h, 8

9 Sondang P. Siagian, pengertian-tentang-efektivitas. html (Internet, http://othenk.blogspot.com/

${ }^{2} 008 / 11 /$ pengertian-tentang-efektivitas.html diakses Jum'at 27 Januari 2012
} 
dan wawasan luas terhadap perubahan yang terjadi dan kompetisi psikomotor yaitu penguasaan sejumlah ketrampilan yang berkaitan dengan bidang studi garapannya. Guru yang professional juga harus mampu mendisiplinkan diri dalam mengatur waktu untuk kepentingan diri, tugas dan kemasyarakatan. ${ }^{10}$

Pengertian professional yang terdapat dalam dalam undang-undang (UU) Guru dan Dosen adalah pekerjaan atau kegiatan yang dilakukan oleh seseorang dan menjadi sumber penghasilan kehidupan yang memerlukan keahlian dan menjadi sumber penghasilan kehidupan yang memerlukan keahlian, kemahiran, atau kecakapan yang memenuhi standar mutu atau norma tertentu serta memerlukan pendidikan profesi. ${ }^{11}$

\section{Pengertian dan Tujuan MGMP}

MGMP adalah suatu forum atau wadah profesional guru mata pelajaran yang berada pada suatu wilayah kabupaten/ kota/kecamatan/ sanggar/gugus sekolah, yang ruang lingkupnya meliputi guru mata pelajaran, baik yang berstatus PNS maupun Swasta. Prinsip kerjanya adalah cerminan kegiatan "dari, oleh, dan untuk guru" dari semua sekolah. Atas dasar ini, maka MGMP merupakan organisasi nonstruktural yang bersifat mandiri, berasaskan kekeluargaan, dan tidak mempunyai hubungan hirarkis dengan lembaga lain. ${ }^{12}$

Dalam Buku Panduan Musyawarah Guru Mata Pelajaran Madrasah Tsanawiyah, Madrasah Aliyah dan Madrasah Aliyah Kejuruan, Pengertian MGMP menurut Firdaus adalah wadah kegiatan profesional untuk

\footnotetext{
${ }^{10}$ Hadirja Paraba. 2000. Wawasan Tugas Tenaga Guru dan Pembina PAI, (Jakarta:Friska Agung Insani), h. 9

${ }^{11}$ Dirjen Pendidikan Islam, 2007. Kumpulan UndangUndang dan Peraturan Pemerintah RI Tentang Pendidikan, (Jakarta: Departemen Agama), h.25

${ }^{12}$ Ahmad Arief, 2004. Memberdayakan MGMP Sebuah Keniscayan (Internet: www.geogle Arief mangkoesapoetro.com), diakses Kamis 15 Desember 2011
}

meningkatkan pengetahuan dan kemampuan serta untuk membina hubungan kerjasama secara kemitraan dan fungsional antara sesama Guru mata pelajaran yang ada di MTs/ MA/MAK, yang tergabung dalam organisasi setingkat gugus dengan memanfaatkan potensi/kemampuan yang ada pada masingmasing guru. MGMP dibentuk atas inisiatif guru dalam rangka peningkatan mutu pendidikan (dari, untuk dan oleh guru $)^{13}$

MGMP MTs/MA/MAK dibentuk dengan basis mata pelajaran atau rumpun mata pelajaran dan gugus dengan jumlah anggota 5 30 orang guru yang berasal dari 2 (dua) satuan pendidikan atau lebih. Gugus yang dimaksud adalah lingkup lokasi tugas atau tempat tinggal yang saling berdekatan sehingga memungkinkan bagi guru untuk berkumpul atau melakukan pertemuan secara mudah; tanpa halangan jarak atau lokasi. Pembentukan MGMP juga dimungkinkan dengan basis kewilayahan, seperti kecamatan, kabupaten/ kota atau provinsi, tetapi bukan merupakan keharusan $^{14}$.

MGMP MTs/MA/MAK bertujuan untuk: Pertama, Membina kemampuan akademik serta meningkatkan kompetensi guru sesuai mata pelajaran atau rumpun mata pelajaran ,masing-masing. Kedua, meningkatkan rasa kebersamaan dan tanggung jawab sebagai pendidik pada MTs/MA/MAK untuk menciptakan budaya belajar yang unggul dalam menghasilkan keluaran (lulusan) yang berkualitas. Ketiga, menumbuhkan kegairahan Guru MTs/MA/MAK dalam mempersiapkan, melaksanakan dan mengevaluasi program Kegiatan Belajar Mengajar (KBM). Keempat, mengurangi kesenjangan kompetensi antar Guru MTs/MA/MAK sehingga dapat menunjang usaha peningkatan dan pemerataan mutu MTs/MA/MAK. Kelima, mengidentifikasi permasalahan yang dihadapi

13 Depag RI. Direktorat Pendidikan Madrasah. 2007, Panduan Guru Mata Pelajaran Madrasah Tsanawiyah, Madrasah Aliyah, dan Madrasah Aliyah Kejuruan. Jakarta ${ }^{14} \mathrm{Ibid}$ 
Guru MTs/MA/MAK dalam melaksanakan tugas sehari-hari dan bertukar pikiran untuk mencari alternatif penyelesaiannya. Keenam, membantu Guru MTs/MA/MAK dalam upaya memenuhi kebutuhannya yang berkaitan tugas profesionalnya sebagai pendidik. Ketujuh, membantu Guru MTs/MA/MAK memperoleh berbagai informasi kependidikan, baik yang menyangkut kebijakan pendidikan maupun teknis pembelajaran. Kedelapan, membantu Guru MTs/MA/MAK untuk bekerjasama dalam meningkatkan mutu kegiatan pembelajaran, baik yang terstruktur maupun yang tidak terstruktur. Kesembilan, memperluas wawasan dan saling tukar menukar informasi dan pengalaman antar guru MTs/MA/MAK agar tetap mengikuti perkembangan yang terjadi terkait dengan pendidikan dan pembelajaran. Kesepuluh, meningkatkan semangat untuk memacu diri dan meraih prestasi terbaik dalam pendidikan dan pembelajaran. ${ }^{15}$

Sedang tugas dan tanggung jawab MGMP MTs/MA/MAK adalah sebagai berikut:

1. Memberikan motivasi kepada guruguru MTs/MA/MAK agar terus menerus meningkatkan kompetensi dan profesionalisme dalam rangka pengembangan diri.

2. Meningkatkan kompetensi guru MTs/MA/ MAK dalam melaksanakaan kegiatan belajar mengajar dengan memanfaatkan potensi/ kemampuan yang ada pada masing-masing guru untuk belajar bersama atau bertukar pengalaman sehingga dapat menunjang usha peningkatan dan pemerataan mutu pendidik dan tenaga kependidikan.

3. Membantu pemenuhan kebutuhan guru MTs/MA/MAKyang berkaitan dengan kegiatan belajar mengajar, khususnya yang menyangkut pengembangan kurikulum pada tingkat satuan pendidikan dan pelaksanaan pembelajaran.

4. Memberikan pelayanan konsultasi dalam mengatasi permasalahan Guru MTs/MA/

\footnotetext{
${ }^{15}$ Ibid
}

MAK khususnya terkait proses belajar mengajar.

5. Menyebarkan informasi tentang perkembangan baru dan atau kebijakan terkaait pendidikan dan pembelajaran.

6. Merencanakan, melaksanakan, dan mengevaluasi kegiatan kelompok seta menetapkan rencana kegiatan tindak lanjut.

7. Menjalin kerjasama dan kemitraan dengan forum sejenis, daan konsultasi dengan instansi terkait terutama dengan Departemen Agama dan Dinas Pendidikan setempat, sesuai tingkatan masin-masing.

8. Memberikan masukan dan pertimbangan kepada Kantor Departemen Agama, Kantor Wilayah Departemen Agama dan Direktorat Pendidikan Madrasah . terkait kebijakan pendidikan, khususnya terkait dengan peningkatan mutu guru dan mutu pembelajaran.

9. MGMP MTs/MA/MAK pada tingkat kabupaten/kota, provinsi atau nasional. Menjadi forum kordinasi bagi MGMP MTs/ MA/MAK tingkat gugus atau lingkup yang lebih kecil wilayahnya.

\section{Metode Penelitian}

Penelitian ini menggunakan pendekatan mixed method yaitu penelitain kualitatif yang di dukung oleh data-data kuantitaif. Metode analisisnya adalah deskriptif presentatif dan untuk mengetahui tingkat efektifitasnya dengan kategori: (a) $90 \%-100 \%=$ Sangat Efektif, (b) $80 \%-89 \%=$ Efektif, (c) $65 \%-79 \%=$ Cukup Efektif, (d) $55 \%$ - 64\% = Kurang Efektif, dan (e) dibawah 55\% = Tidak efektif.

Responden dalam penelitian terdiri dari 14 ketua MGMP, 140 Guru yang menjadi anggota MGMP, 7 Kasi Mapenda, 7 Ketua Pokjawas, dan14 Kepala Madrasah sebagai pembina sanggar MGMP yang tersebar di tujuh propinsi. Teknik pengambilan sampel dengan menggunakan teknik Stratified Random Sampling . 
Instrumen pengumpul data yang digunakan dalam penelitian ini terdiri dari angket tertutup, angket terbuka dan pedoman wawancara. Angket tertutup digunakan untuk menjaring data primer tentang efektifitas (tujuan dan kegiatan) MGMP dalam membina profesional guru mata pelajaran umum. Angket terbuka digunakan untuk menjaring data primer tentang profil MGMP di masing-masing gugus. Dan pedoman wawancara digunakan untuk melakukan croschek terhadap data sekunder tentang efektifitas tujuan dan kegiatan MGMP

\section{HASIL DAN PEMBAHASAN}

\section{Efektivitas MGMP Mata Pelajaran Umum dalam Peningkatan Profesionalisme Guru di MTs}

Penemuan penelitian ini diungkapkan tentang efektivitas MGMP dalam membina kemampuan profesionalitas guru mata pelajaran umum di MTs, dilihat dari kegiatankegiatan MGMP sesuai dengan tujuan dan fungsinya. Adapun kegiatan-kegiatan MGMP tersebut dikelompokkan menjadi 6 segi yaitu: (1) MGMP dilihat dari segi kebutuhan guru, (2) MGMP terhadap pengembangan kemampuan dan keterampilan guru, (3) MGMP terhadap pengembangan profesi dan wawasan pendidikan, (4) MGMP terhadap pengembangan minat dan kegiatan kemasyarakatan, (5) MGMP terhadap pengembangan sumber dana, dan (6) MGMP dalam berkoordinasi, Jaringan kerjasama dan laporan. Adapun hasil efektivitasnya sebagai berikut:

\section{Efektivitas MGMP terhadap Kebutuhan Guru}

HasilpenelitianMGMPterhadapkebutuhan gurumencapai 85\% respondenmenjawabsangat efektif, hal ini dapat diartikan bahwa MGMP sangat dibutuhkan guru dalam meningkatkan profesionalisme guru, kemampuan akademik guru, kompetensi guru dalam mengajar, menumbuhkan semangat guru dalam mempersiapkan kegiatan belajar mengajar guru dan mengurangi kesenjangan antar guru dalam proses pembelajaran. Peningkatan kemampuan guru dalam pelaksanaan proses belajar mengajar merupakan bagian dari usaha peningkatan mutu pendidikan, dimana guru mempunyai peranan yang sangat penting yaitu sebagai perencana, pelaksana dan dinamisator kurikulum dan bahan ajaran yang dilaksanakan sesuai dengan tingkat dan perkembangan peserta didik melalui penguasaan didaktik dan metodik. Seiring dengan fenomena tersebut di atas, pembangunan pendidikan yang lebih berkualitas telah dilaksanakan melalui berbagai upaya seperti, pengembangan dan perbaikan kurikulum, pemenuhan sarana dan prasarana pendidikan, sistem evaluasi, pengembangan bahan ajar, pelatihan guru dan tenaga pendidik, dan usaha lainnya.

MGMP merupakan wadah yang cukup efektif dalam meningkatkan kebutuhan guru, dalam peningkatan profesionalisme guru terhadap kebutuhannya dalam proses pembelajaran hal ini terlihat dari jawaban responden bahwa MGMP sangat membantu dalam meningkatkan kemampuan guru dalam menyiapkan bahan ajar, melakukan evaluasi terhadap proses pembelajaran serta meningkatkan profesionalisme guru dalam proses belajar mengajar. Dengan demikian dapat dikatakan bahwa kegiatan MGMP terhadap kebutuhan guru di MTs sangat efektif terhadap pemenuhan kebutuhan guru disekolah. Untuk itu MGMP mata pelajaran umum di MTs perlu dikembangkan lebih baik lagi dalam rangka pemenuhan kebutuhan guru sebagai pendidik, karena melalui MGMP itulah guru bisa mendapatkan pengalaman dan pembelajaran.

Efektivitas MGMP terhadap Pengembangan Kemampuan dan Keterampilan guru

Hasil penelitian efektivitas MGMP terhadap pengembangan kemampuan dan ketrampilan guru mencapai $70 \%$ responden 
menjawab cukup efektif dan sisanya menyatakan tidak efektif. MGMP juga mempunyai pengaruh yang signifikan dalam pengembangan kemampuan dan ketrampilan guru dalam proses pembelajaran misalnya mendiskusikan isi kurikulum, membuat perencanaan pembelajaran, menyusun program pembelajaran dan lain-lain. Hal ini sesuai dengan standar nasional pendidikan mengisyaratkan, bahwa proses pembelajaran pada suatu pendidikan diselenggarakan secara interaktif, inspiratif, menyenangkan, menantang, memotivasi peserta didik untuk berpartisipasi aktif serta memberikan ruang yang cukup bagi prakarsa, kreatifitas, dan kemandirian sesuai dengan bakat, minat, dan perkembangan fisik serta psikologis peserta didik. Oleh karena setiap satuan pendidikan hendaknya melakukan perencanaan, proses pembelajaran, pelaksanaan proses pembelajaran, penilaian hasil pembelajaran dan pengawasan proses pembelajaran untuk terlaksananya proses pembelajaran yang efektif dan efesien.

Tuntutan proses pembelajaran tersebut menuntut guru untuk selalu mengembangkan diri agar dapat memenuhi terlaksananya proses pembelajaran secara maksimal. Dilain pihak kegiatan pembelajaran dilapangan masih menemui masalah dan hambatan. Atas dasar pemikiran tersebut, maka bagi guru dibutuhkan wadah yang dapat menginventarisasikan masalah dan hambatan tersebut. Forum MGMP merupakan salah satu alternatif pemecahan masalah dan hambatan guru dalam proses pembelajaran, dimana dalam MGMP berusaha untuk saling berbagi pengalaman, pengetahuan dan terus berefleksi/berdiskusi. Kontribusi nyata kegiatan MGMP yang telah dirasakan pada guru adalah sebagai berikut: sebagai wadah dalam mendiskusikan isi kurikulum satuan pelajaran sesuai dengan rumpun mata pelajaran, sebagai wadah bagi guru untuk menyusun KTSP dan implementasinya, sebagai wadah bagi guru untuk mengadakan konsultasi tentang perkembangan mata pelajaran, efektif sebagai wadah bagi guru dalam menyusun rencana program pembelajaran, dll.

Dengan demikian MGMP sangat membantu sekalibagiguru-guru mata pelajaran umum MTs dalam rangka peningkatan kemampuan dan ketrampilan guru dalam proses pembelajaran disekolah, karena pada umumnya kemampuan guru dalam proses mengajar tidaklah sama, dengan adanya MGMP mata pelajaran umum ini maka guru bisa mendiskusikan segala hal yang berkaitan dengan pengembangan dan ketrampilan yang harus dimiliki oleh seorang guru yang profesional. Oleh sebab itu MGMP mata pelajaran guru sangat diperlukan sebagai wadah dalam meningkatkan profesionalisme guru dalam proses pembelajaran. Upayauapaya tersebut perlu dilakukan dengan mengerahkan seluruh potensi yang dapat mendukung peningkatan mutu pendidikan.

\section{Efektivitas MGMP terhadap Pengembangan Profesi dan Wawasan Pendidikan}

Pengembangan sumber daya manusia pendidik, khususnya pengembangan profesional guru, merupakan usaha mempersiapkan guru agar memiliki berbagai wawasan, pengetahuan, keterampilan, dan memberikan rasa percaya diri untuk melaksanakan tugas dan kewajibannya sebagai petugas profesional Pengembangan atau peningkatan kemampuan profesional harus bertolak pada kebutuhan atau permasalahan nyata yang dihadapi oleh guru, agar bermakna. Undangundang Republik Indonesia Nomor 14 Tahun 2005 tentang Guru dan Dosen pasal 20 ayat (b) mengamanatkan bahwa dalam rangka melaksanakan tugas keprofesionalannya, guru berkewajiban meningkatkan dan mengembangkan kualifikasi akademik dan kompetensi secara berkelanjutan sejalan dengan perkembangan ilmu pengetahuan, teknologi, dan seni. Kegiatan tersebut sangat dimungkinkan dilaksanakan di Kelompok Kerja Guru (KKG), atau di Musyawarah Guru Mata Pelajaran (MGMP), mengingat wadah ini dijadikan sebagai tempat melakukan 
pertemuan bagi guru kelas atau guru mata pelajaran sejenis.

MGMP dapat meningkatkan wawasan guru dalam proses pembelajaran, dimana melalui MGMP ini guru-guru bisa berbagi pengalaman dan ilmu yang bisa dimanfaatkan oleh guru-guru yang tergabung dalam kelompok tersebut untuk menambah wawasan bagi guru baik itu terhadap proses pembelajaran disekolah maupun informasi tentang kebijakan-kebijakan yang diperlukan untuk meningkatkan profesionalisme guru dalam peningkatan mutu pendidikan, oleh sebab itu berdasarkan hasil penelitian yang didapat dari 140 responden guru yang tersebar diseluruh Indonesia, hampir 67\% responden menjawab bahwa MGMP cukup efektif dan 33\% mengatakan tidak efektif untuk mengupdate informasi tentang kebijakan baru dan tempat menyebar luaskan hasil diklat yang didapat oleh guru, tetapi MGMP juga tidak efektif untuk membantu anggota untuk melanjutkan pendidikan ke yang lebih tinggi, serta tidak efektif bagi guru untuk melakukan penelitian ilmiah, hal ini terlihat dari jawaban responden terhadap indicator pengembangan profesi dan wawasan pendidikan. Dengan demikian dapat disimpulkan bahwa efektifitas MGMP terhadap pengembangan profesi dan wawasan pendidikan tidak sepenuhnya dapat membantu guru dalam hal tersebut, jadi masih ada faktor lain yang bisa membantu pengembangan profesi guru dan wawasan pendidikan bagi guru dalam rangka peningkatan mutu pendidikan.

\section{Efektivitas MGMP terhadap Pengembangan Minat dan Kegiatan Kemasyarakatan}

Hasil penelitian terhadap pengembangan minat dan kegiatan kemasyarakatan hanya $37 \%$ responden yang menjawab efektif, dan sisanya menyatakan tidak efektif, hal ini berarti bahwa MGMP yang sudah terbentuk saat ini masih belum maksimal, kenyataan dilapangan bahwa MGMP sebagai pengembangan minat dan kegiatan kemasyarakatan masih kurang diminati oleh guru, ini mengisyaratkan bahwa guru-guru lebih mementingkan MGMP sebagai wadah untuk menggali proses yang berkaitan dengan kompetensi guru dalam meningkatkan kemampuan guru dalam proses perencanaan pembelajaran. Jadi tujuan MGMP sebagai pengembangan minat dan kegiatan kemasyarakatan belum berjalan sesuai dengan tujuan yang diharapkan, hal ini disebabkan waktu yang cukup singkat dalam pertemuan dan organisasi MGMP di MTs juga belum maksimal dalam menjalankan fungsinya.

Dari segi efektivitas MGMP terhadap pengembangan minat dan kegiatan kemasyarakatan, MGMP mata pelajaran umum di MTs belum berjalan sesuai dengan tujuan. Adapun tujuan yang belum efektif dilaksanakan antara lain: (1) pelaksanaan MGMP sebagai wadah guru dalam menyelenggarakan lomba yang berkaitan dengan mata pelajaran, (2) menyelenggarakan bakti sosial terhadap masyarakat, (3) menyelenggarakan pelatihan ilmiah dalam masyarakat, dan (4) menyelenggarakan layanan pendidikan luar sekolah dalam masyarakat. Dengan demikian MGMP Mata Pelajaran Umum di Mts saat ini belum efektif dalam pengembangan minat dan kegiatan masyarakat dikarenakan guru-guru mata pelajaran umum pada umumnya masih beranggapan bahwa MGMP itu sangat efektif untuk meningkatkan professionalisme yang berkaitan dengan proses yang berhubungan langsung dalam peningkatan skill guru.

\section{Efektivitas MGMP terhadap Pengembangan Sumber Dana}

Hasil penelitian efektifitas MGMP dalam pengembangan sumber dana masih kurang efektif hal ini terlihat dari jawaban responden hanya sekitar $45 \%$ yang menyatakan efektif. Faktor sumber dana dalam menjalankan organisasi MGMP sangat diperlukan untuk kelancaran kegiatan MGMP MTs di semua daerah, karena hal ini merupakan faktor penting agar MGMP yang sudah terbentuk 
bisa berjalan sesuai dengan tujuan yang sudah ditetapkan. Apabila MGMP tidak mendapatkan bantuan dana dari pemerintah maka organisasi tersebut akan sulit berjalan dengan maksimal. Hal ini terlihat bahwa MGMP tidak dapat diandalkan dari sumbangan dari anggota maupun sumbangan sukarela dari masyarakat. Untuk itu dalam hal ini perlu perhatian dari pemerintah untuk mengkaji ulang organisasi MGMP dalam peningkatan profesionalisme guru dan organisasi ini perlu diawasi dan diberikan bantuan agar tujuan MGMP untuk peningkatan mutu guru dapat berjalan dengan baik.

\section{Efektivitas MGMP terhadap Koordinasi, Jaringan Kerjasama dan Laporan}

Berdasarkan temuan penelitian tentang efektivitas MGMP terhadap koordinasi, jaringan kerjasama dan laporan berjalan kurang efektif antara lain: (1) kurang terbinanya hubungan fungsional antara MGMP dengan Kepala Kandepag Kota/Kabupaten, (2) kurang terbina hubungan fungsional dan pembinaan edukatif antara MGMP dengan kasi Mapenda, (3) kurang terbina hubungan koordinatif dan pembinaan antara MGMP dengan pengawas, (4) kurang terbina hubungan koordinasi/ konsultasi antara MGMP dengan pengawas, (5) kurang terbina hubungan koordinasi/ konsultasi antara MGMP dengan Departemen agama setempat, (6) kurang terbinanya kerja sama antara MGMP dengan Dinas, (7) kurang terbinanya hubungan MGMP dengan perguruan tinggi, (8) kurang terbinanya kerja sama antara MGMP dengan komite sekolah, (9) kurang terbinanya kerja sama antara MGMP dengan PSBB, (10) pengurus MGMP kurang efektif melaporkan hasil kegiatan kepada unit terkait, (11) MGMP kurang efektif melaporkan perencanaan pelaksanaan dan hasil kegiatan secara berkala kepada pengawas madrasah dan (12) MGMP kurang efektif melaporkan perencanaan pelaksanaan dan hasil kegiatan secara berkala kepada Kasi Mapenda Kandepag Kota/Kabupaten. Hal ini disebabkan karena
MGMP mata pelajaran umum sebagian besar belum berjalan dengan baik yang disebabkan oleh beberapa faktor, sehingga berdampak pada koordinasi, jaringan kerjasama antar guruguru mata pelajaran umum belum terlaksana dengan baik. Apabila MGMP matapelajaran umum sudah berjalan dengan maksimal maka secara tidak langsung koordinasi antar guruguru mata pelajaran umum akan terbina dengan baik sesuai dengan kebutuhan guru dalam pengembangan kemampuannya sebagai guru yang profesional.

\section{Kendala yang dihadapi MGMP Mata Pelajaran Umum di MTs dalam Peningkatan Profesionalisme Guru}

Berdasarkan temuan tersebut di atas dapat dijelaskan bahwa kecendrungan MGMP mata pelajaran umum di MTs belum berjalan efektif. dikarenakan pelaksanaan MGMP mata pelajaran umum di MTs dalam pembinaan profesionalisme guru terdapat beberapa kendala antara lain:

Menurut ketua MGMP IPA dari MTS Serang "Dra. Lia Hastuti" mengungkapkan bahwa kendala yang dihadapi dalam pelaksanaan kegiatan MGMP adalah alokasi waktu yang tidak cukup untuk mengakomodir kebutuhan pelaksanaan kegiatan pelatihan MGMP IPA, sarana dan prasarana yang dibutuhkan terbatas, sehingga tidak semua peserta dapat mengunakan alat praktek dan alat yangtersedia pada kegiatan tersebut tidak dimiliki oleh madrasah tempat asal peserta, sehingga apa yang diperoleh dari pelatihan tersebut tidak dapat dipraktekkan kembali dihadapan peserta didik. Dan di MTs tempat peserta mengajar rata-rata masih banyak yang belum memiliki Laboratorium IPA. Adapun problem organisasi yang dialami MGMP dalam menjalankan tugas, menurut Lia Hastuti adalah bantuan dana dari subsidi pemerintah melalui pemberdayaan MGMP sangat terbatas dan masih tidak mencukupi, guru mata pelajaran yang masih mismet, sehingga tidak sesuai dengan keahlian yang dimilikinya (profesionalime kompetensi 
guru sangat rendah). Sedang pada problem pembinaan adalah sertifikasi bidang studi masih kurang dan jarak antar madrasah sangat jauh, sehingga pertemuan masih jarang. Untuk mengatasi problem tersebut perlu adanya jadwal pertemuan rutin dan dukungan tambahan dana dari DIPA sehingga MGMP semakin Aktif. Begitu juga menurut Drs. Zaidin Burhani M.Pd Kasi Mapenda Kabupaten Bandung menyatakan saat ini koordinasi antara Mapenda, gugus MGMP dan Pengawas belum dilaksanakan secara maksimal karena padatnya tugas-tugas rutin dan kegiatan lintas sektoral. Namun demikian tetap perlunya penertiban organisasi MGMP dengan menerbitkan SK Kandepag atas usulan hasil Musyawarah Anggota.

Selanjutnya Muh. Arsyad Ketua Pokjawas Kota Pontianak, mengungkapkan bahwa problem yang dialami MGMP sebagai wadah musyawarah guru-guru, antara lain: kebijakan pejabat pembina (Bidang/Seksi Mapenda) dalam memberikan penekanan untuk terbentuknya MGMP masih kurang, pembinaan yang dilakukan oleh Pejabat dari Kanwil Dep. Agama maupun pejabat dari Kantor Dep. Agama Kab./Kota belum terprogram dengan baik. Kemudian dana operasional MGMP masih bersifat bantuan, bahkan bantuan tersebut lebih cenderung bersifat insedental dan jumlahnya sangat terbatas (masih kurang) dibanding biaya/anggaran kegiatan yang telah disusun oleh MGMP, sebagai akibatnya sebagian besar kegiatan yang telah diprogramkan tidak dapat dilaksanakan sebagaimana mestinya. Selanjutnya sampai saat ini koordinasi antara MGMP, Kabid Mapenda, Kasi Mapenda dan Pengawas belum berjalan dengan baik, bahkan lebih cenderung koordinasi tersebut tidak berjalan sebagaimana mestinya. Kemudian kendala lainnya adalah di lingkungan Dep. Agama tidak ada kebijakan untuk mengangkat pengawas mata pelajaran umum, salah satu akibatnya adalah MGMP mata pelajaran umum di MTs sampai saat belum berjalan atau belum terbentuk.
Drs. Ramli US, Ketua Pokjawas Madrasah Kota Jambi mengungkapkan bahwa kendalakendala terhadap efektifitas MGMP mata pelajaran umum di MTs antara lain belum terbentuknya MGMP mata pelajaran umum, belum memiliki panduan khusus tentang pembinaan MGMP, sangat minimnya dana, belum adanya bantuan dari pihak lain, sulitnya mengumpulkan dana dari anggota, belum ada ketegasan apakah koordinasi guru-guru mata pelajaran umum kepada pengawas atau Mapenda dan MGMP belum termasuk dalam perkiraan jam wajib tatap muka bagi guru sehingga menghambat kehadiran guru.

MenurutPokjawas madrasah dikota Medan (Dra. Syufriati Siagian dan Drs. Pangadilan Hasibuan) yang menyebabkan belum efektifnya kegiatan MGMP mata pelajaran umum di MTs antara lain dikarenakan tidak jelasnya peraturan pemerintah tentang struktur organisasi MGMP mata pelajaran umum, adanya kesenjangan MGMP di sekolah swasta dan negeri, (kedudukan di organisasi seolah Negeri diutamakan), kedudukan pengurus/ anggota yang tersebar di sekolah/madrasah yang jaraknya jauh sukar untuk berkoordinasi, kurangnya tenaga yang mampu untuk membina terutama di daerah yang jauh dari perkotaan, kurangnya informasi baru di daerah terpencil terutama menyangkut informasi baru dalam pembelajaran, keterbatasan guru membagi waktu untuk hadir mengikuti pembinaan MGMP, dana MGMP belum merata ke semua daerah, pengaturan sebagai dana mandiri di sekolah negeri belum ada, sekolah swasta terutama yang besar belum terbiasa mengalokasikan RAPBM nya untuk kegiatan MGMP, jarak tempat pengurus yang berjauhan terutama di daerah terpencil mengakibatkan sulit untuk koordinasi, padatnya jam wajib tatap muka bagi guru sebagai pengurus MGMP, sulit untuk membagi waktu berkoordinasi memajukan MGMP, dan MGMP belum termasuk dalam perkiraan jam wajib tatap muka bagi guru sehingga menghambat kehadiran guru. 
Selanjutnya menurut Kepala Mapenda Depag Sidoarjo mengungkapkan bahwa MGMP mata pelajaran umum di Sidoarjo belum mempunyai kinerja yang optimal, karena ada beberapa faktor yang mempengaruhi, antara lain ukuran organisasi yang sangat besar sehingga ketersediaan dana tidak mencukupi untuk melibatkan para anggotanya, manajemen belum mapan, dukungan para stakeholder yang masih kurang, di samping pembentukan MGMP dan pelaksaan kegiatanya belum sesuai dengan struktur yang ada di Madrasah.

Sementara itu, menurut Drs. Sumarwan, M.Ag ketua MGMP KKM MTsN Klaten, Pelaksanaan program-program MGMP masih banyak terkendala oleh ketiadaan tenaga khusus yang siap dalam melaksanakan program sesuai perencanaan, hal ini akibatnya tidak ada tenaga khusus dalam melaksanakan kegiatan teknis MGMP. Masalah lainnya sekretariat khusus untuk MGMP yang belum memadai, sumber dana yang terbatas, sehingga ketika melaksanakan program dan ketika ingin menghadirkan narasumber yang berkualitas, misalnya narasumber dari instansi lain mengalami kendala.

Berdasarkan hasil penelitian tersebut bahwa MGMP mata pelajaran umum masih banyak mengalami kendala yang dihadapi dilapangan, apabila ditinjau dari tujuan dan peran MGMP seperti diatas, MGMP adalah suatu wadah yang strategis untuk meningkatkan kompetensi guru dan siswa dalam rangka meningkatkan mutu pendidikan secara umum. Tetapi melihat kenyataan dilapangan keberadaan MGMP masih banyak keterbatasan. Keterbatasan tersebut dapat terlihat dari sumber daya manusia, keterlibatan pengurus dan peserta belum optimal, dana operasional yang terbatas, koordinasi antar MGMP dan pembinaan serta perhatian dari stakeholder pendidikan masih belum optimal. Melihat keterbatasan yang ada, perlu kiranya semua pihak terterlibat dan stakeholder pendidikan berpacu mengatasi secara bersama-sama agar semua keterbatasan yang ada dalam organisasi
MGMP dapat dicarikan jalan pemecahannya. Jika dicermati, tampaknya dana menjadi problem serius bagi pengurus MGMP dalam menjalankan program, baik jangka panjang, menengah, maupun pendek. Bagaimana mungkin guru mata pelajaran mampu mengembangkan kompetensi pedagogik dan profesionalnya kalau tak pernah diajak untuk berkiprah mengikuti kegiatan-kegiatan MGMP yang cerdas, kreatif, dan mencerahkan.

Keberadaan MGMP Mata Pelajaran Umum secara organisatoris telah ada dan berfungsi. Namun kadang-kadang sistem pelaksanaan programnya kurang efektif sehingga tujuan yang diharapkan tidak tercapai secara optimal. Selama ini MGMP Mata Pelajaran umum melakukan kegiatan diskusi untuk menyamakan persepsi mengenai perubahan kurikulum, membahas berbagai permasalahan yang muncul baik spesifik maupun umum yang berkaitan dengan pembelajaran Akuntansi. Bagi sebagian guru kegiatan MGMP sangat membantu akan tetapi sebagian guru yang lain menganggap bahwa kegiatan MGMP merupakan kegiatan klasik, hanya berkumpul untuk bertemu teman seprofesi tanpa membawa hasil bukan dilandasi motivasi yang tinggi akan pentingnya wawasan dan pengetahuan untuk meningkatkan kompetensi agar menjadi guru yang profesional.

\section{PENUTUP}

\section{Kesimpulan}

Berdasarkan temuan penelitian dan pembahasan dapat disimpulkan bahwa MGMP mata pelajaran umum masih belum berjalan dengan maksimal hal ini terlihat dari hasil penelitian bahwa MGMP saat ini hanya efektif dalam peningkatan kebutuhan guru serta pengembangan kemampuan dan ketrampilan guru, misalnya Mendiskusikan, menyusun dan atau mengembangkan kurikulum tinngkat satuan pendidikan dan implementasinya sesuai dengan mata pelajaran atau rumpun mata pelajaran masing-masing; Membantu 
anggota dalam menyusun program kerja pembelajaran; Mendiskusikan pendalaman mateeri pembelajaran, pengembangan dan penggunaan strategi, metode, dan media pembelajaran untuk mata pelajaran atau rumpun mata pelajaran sesuai bidangnya; Membantu anggota dalam pengembangan instrumen dan pelaksanaan evaluasi pembelajaran dan hasil belajar peserta didik untuk mata pelajaran atau rumpun mata pelajaran sesuai bidangnya.

Sementara tujuan MGMP dalam pengembangan profesi dan wawasan pendidikan seperti menyelenggarakan seminar, lokakarya, pelatihan-pelatihan belum berjalan maksimal dan koordinasi antar guru-guru mata pelajaran umum masih belum berjalan dengan baik, hal ini terlihat bahwa di daerah penelitian yang dilakukan bahwa keberadaan MGMP mata pelajaran umum belum maksimal hal ini disebabkan manajemen organisasi yang belum baik, jarak dan waktu juga menjadi faktor belum berjalannya MGMP mata pelajaran umum di MTs, bantuan dana untuk pemberdayaan MGMP sangat terbatas, terbatasnya sarana dan prasarana yang dibutuhkan, Kibijakan pejabat pembina ( Bidang / Seksi Mapenda) untuk pemberdayaan MGMP masih kurang, Pembinaan yang dilakukan pejabat belum terprogram, Koordinasi antara MGMP , Kabid / Kasi Mapenda dan pengawas belum berjalan dengan baik, Masih banyak MGMP yang belum terbentuk, Belum memiliki panduan khusus tentang pembinaan MGMP, Belum adanya ketegasan koordinasi antara guru, pengawas, Mapenda, dan MGMP, Tidak jelasnya struktur organisasi MGMP, Adanya kesenjangan MGMP swasta dan negeri, dan Kondisi geografis yang berjauhan sehingga sulit berkoordinasi.

\section{Saran-saran}

Berdasarkan kesimpulan hasil penelitian ini dapat diajukan beberapa saran yang diperlukan untuk meningkatkan efektivitas MGMP dalam membina profesionalitas guru mata pelajaran umum di MTs sebagai berikut:
1. Disarankan kepada Ditjen Pendidikan Islam Kementerian Agama RI, Direktorat Pendidikan Madrasah sebagai policy maker memberikan regulasi untuk pengembangan MGMP agar lebih efektif dalam pembinaan profesionalitas guru mata pelajaran umum baik menyangkut tata kelola organisasi MGMP maupun pendanaanya.

2. Kepada Kantor Wilayah Kementerian Agama dan Kantor Kementerian Agama Kota/Kabupaten sebagai pembina MGMP di wilayah disarankan dapat meningkatkan pemberdayaan dan intensitas pembinaan MGMP pelajaran umum di MTs melalui perencanaan program yang matang termasuk didalamnya menyangkut pengaturan waktunya.

3. Bagi Pengawas sebagai pembina di madrasah disarankan untuk lebih meningkatkan profesionalitasnya sehingga intensitas dan efektivitas dalam pembinaan MGMP akan meningkat.

4. BagiKepalasekolahselakupembinasanggar MGMP disarankan untuk meningkatkan koordinasi baik kepada Kanwil Kemenag, Kasi Penmad, maupun pengawas untuk mengatur pembinaan MGMP sehingga akan lebih meningkatkan efektivitas dalam meningkatkan profesionalisme guru.

5. Pengurus dan anggota MGMP mata pelajaran umum disarankan untuk meningkatkan pemberdayaan MGMP dengan melalui pemantapan manajemen, pembentukan Anggaran Dasar dan Anggaran Rumah Tangga, pengembangan anggota pada MTs swasta, dan bekerjasama dengan berbagai pihak termasuk dengan MGMP pada SMP, sehingga dengan demikian MGMP diharapkan akan lebih efektif dalam membina profesionalitas guru mata pelajaran umum di MTs. 


\section{SUMBER BACAAN}

Abustam, Idrus HM, et al, (1996): Pedoman Praktis Penelitian dan Penulisan Karya Ilmiah,Ujung Pandang: Lembaga Penelitian IKIP

Ahmad Arief, (2004): Memberdayakan MGMP Sebuah Keniscayan (Internet: www. geogle Ariefmangkoesapoetro.com)

Departemen Agama RI. Direktorat Pendidikan Madrasah. 8 Januari 2007, Panduan Musyawarah Guru Mata Pelajaran Madrasah Tsanawiyah, Madrasah Aliyah, dan Madrasah Aliyah Kejuruan. Jakarta,.

Departemen Agama RI, Direktorat Jendral Pendidikan Islam Direktorat Pendidikan Islam pada sekolah 2008, Pedoman Musyawarah Guru Mata Pelajaran Pendidikan Agama Sekolah Menengah Pertama

Departemen pendidikan nasional, Direktorat Jenderal Peningkatan Mutu Pendidik dan Tenaga Kependidikan, Direktorat Pembinaan Pendidikan dan Pelatihan, (2008): Supervisi Pemberdayaan KKG dan MGMP, Jakarta
Nugraha S. Mulyasa, Meningkatkan Mutu Madrasah Melalui Pemberdayaan MGMP (Internet: http://h4j4r.multiply.com/ journal/item/6/)

Ricky W.Griffin, (2004): Manajemen. Jakarta: Erlangga,

Suaidillah dan Ella Agustina, Rabu 22 Nopember 2006, Memberdayakan KKG dan MGMP (Internet:http://www. radarbanjarmasin.com/berita/index.asp? Berita $=$ Opini\&id $=60089$,

Soedijarto, (1989): Menuju Pendidikan Nasional yang Relevan dan Bermutu, Jakarta:

Balai Pustaka.

Sumarni dkk, (2007): Laporan Hasil Penelitian Kompetensi Guru Mata Pelajaran Umum di Madrasah, Puslitbang Pendidikan Agama dan Keagamaan. 